\title{
Performance of MSMe On Community Welfare (Case Study of MSMe Women in Bambu Kuning Market Bandar Lampung)
}

\author{
Mulyani $^{1}$, Erna Listyaningsih ${ }^{2}$, dan Eka Sariningsih ${ }^{3}$ \\ \{mulyaniadam1989@gmail.com ${ }^{1}$, ernatya04@yahoo.com ${ }^{2}$, Ekasariningsih@yahoo.com ${ }^{3}$ \} \\ Universitas Malahayati, Bandar Lampung, Indonesia
}

\begin{abstract}
In general, the development of Micro, Small and Medium Enterprises (MSMEs) still faces many obtacles, besides the challenges for MSME women are limited time and space related to the dual role of women in business and family. From previous studies found that women have a lower level of financial knowledge than men. The purpose of this study was to determine the performance indicators of MSME women in the Bambu Kuning Market towards the welfare of the community. The performance in this study used indicators of financial literacy, education level, entrepreneurial orientation, independence, emotional intelligence, motivation, financial aspects, and the ability to prepare financial statements. The results showed that independence, emotional intelligence, motivation, and the ability to compile financial reports had a significant effect on the performance of MSME women in the Bambu Kuning Market, while financial literacy, education level, entrepreneurial orientation, and financial aspects did not significantly influence MSME performance. However, in general, the performance of MSME women in the Bambu Kuning Market influenced the welfare of the community. This indicates that the unique abilities of MSME women in the Bambu Kuning Market play a role in improving people's welfare.
\end{abstract}

Keywords: Performance of MSME Women, Community Welfare, Bambu Kuning Market

\section{Introduction}

International Finance Corporation (IFC) notes that in 2015 there were 53.9\% of Micro, Small and Medium Enterprises (MSMEs) in Indonesia owned by women with generally smaller and informal business scales. This study aims to analyze the condition of MSMEs, especially those owned by women, the constraints faced, and provide stakeholder recommendations [1]. In general, in its development, MSMEs are also still experiencing problems, besides the challenges for MSME women are limited time and space related to women's dual role in business and family.

Conventional problems that are not completely resolved are one of the obstacles for MSMEs in their development, such as human resource capacity, ownership, financing, marketing and various other problems related to business management, so that MSMEs are difficult to compete with large companies [2]. Specifically women have lower levels of financial knowledge than men. To overcome problems, especially MSME women, among others, it is 
recommended to make it easier to apply for a business permit for women entrepreneurs, incentives for tax reduction for new entrepreneurs, as well as financial training and education, including the application of mobile banking that can facilitate access to financial services for women entrepreneurs [3]. According to [4] that MSME needs a strategic way to improve the performance and sustainability. Performance is a result of work achieved by a person or organization in carrying out the tasks assigned to it based on skill, experience and sincerity as well as time [5]. The way to do this is by enriching the knowledge of MSME actors towards financial knowledge so that their management and accountability can be better accounted for like large companies. Based on the knowledge of researchers, research on the factors that influence the performance of MSMEs is rare. Additionally the issue of MSME performance on community welfare has not yet specifically examined the performance of MSME women. Therefore, this study investigates this issue.

The term of MSME women in this study are female traders at Bambu Kuning Market in Bandar Lampung.. Bambu Kuning market is one of the traditional markets in Lampung which becomes icon in Bandar Lampung. Therefore this study conducts this issue on this market.

The contribution of these results of this study are expected to be a reference material for local government policy making in facilitating MSME women to gain additional capital and increase MSME knowledge on financial knowledge in order to improve the welfare of the community. Improving the performance of MSMEs in this study is inseparable from the government's efforts to improve the welfare of the community. The performance of MSME in this study is a performance that is seen from internal factors. Internal factors used in this study are Financial Literacy, Education Level, Entrepreneurial Orientation, Independence, Emotional Intelligence, Motivation, Financial Aspects, and Ability to Prepare Financial Statements.

Based on the background previously, the problems that can be described by the author are as follows:

1. Does Financial Literacy affect the Performance of MSME Women?

2. Does the Education Level affect the Performance of MSME Women?

3. Does the Entrepreneurship Orientation affect the Performance of MSME Women?

4. Does Independence affect the Performance of MSME Women?

5. Does Emotional Intelligence affect the Performance of MSME Women?

6. Does Motivation affect the Performance of MSME Women?

7. Does the financial Aspect affect the performance of MSME women?

8. Does the Ability to Prepare Financial Statements affect the performance of MSME women?

9. Does the Performance of MSME Women Affect Community Welfare?

\section{Research Desaign And Methodology}

In this study, the researcher will describe the performance indicators of MSME women namely financial literacy, education level, increase entrepreneurship, independence, emotional intelligence, motivation, financial resources, and the ability to compile financial reports and women's financial assistance Bambu Kuning Market at the Bandar Lampung. The technique of collecting data in this study used the survey method by asking questions directly to female MSMEs at the Bambu Kuning Market in Bandar Lampung. The type of research data used is primary data. In this study the method of analyzing data is using structural equation models (SEM). Questionnaires distributed were 214 sheets or $100 \%$, questionnaires that did not return were 25 sheets or $11.68 \%$, questionnaires were not filled as many as 16 sheets or $7.48 \%$, 
questionnaires that were not criteria were 60 sheets or $28.04 \%$, and questionnaire that can be processed as many as 113 sheets or $52.80 \%$.

\section{Sampling Method}

\section{Population}

Population according to [6] is a generalization area consisting of: objects / subjects that have certain qualities and characteristics set by researchers to be studied and then conclusions drawn. The population in this study were MSME women in the Bambu Kuning Market, Bandar Lampung, amounting to 214 people (Source: Bambu Kuning Market, 2018).

\section{Sampling}

The sample according to [6] is a large part of the number and characteristics possessed by the population. The size of the sample is determined using the Slovin formula [7] as follows:

$$
n=\frac{\mathrm{N}}{1+N e^{2}}
$$

Rounded to 100 samples. in where :

$\mathrm{n}=$ sample size

$\mathrm{N}=$ population size

$\mathrm{e}=$ percent

Allowance for inaccuracy due to sampling errors that are still tolerated or desired in this study is 0.09 .

From the data recorded in the Bambu Kuning Market Office in 2018 the number of trade industries in the Bambu Kuning Market is based on the type of merchandise as much as 459. Therefore the number of samples for research with a margin of error of $5 \%$ is 213,736903 , the number of samples taken in this study rounded out 214 MSME women in the Bambu Kuning Market Bandar Lampung based on the type of merchandise.

\section{Results}

The test path coefficient is used to ensure the relationship between the constructs is strong, the relationship between the constructs is agreed if the path coefficient is greater than 0.100 , then it is declared significant if the path coefficient is at level $>0.050$.

Table 1. PLS structural model; path coefficient, t-statistics 


\begin{tabular}{|c|c|c|c|c|c|}
\hline & $\begin{array}{c}\text { Original } \\
\text { Sample } \\
(O)\end{array}$ & $\begin{array}{c}\text { Sample } \\
\text { Mean } \\
(M) \\
\end{array}$ & $\begin{array}{l}\text { Standard } \\
\text { Deviation } \\
\text { (STDEV) }\end{array}$ & $\begin{array}{c}\text { T Statistics } \\
(|O / S T D E V|)\end{array}$ & $P$ Values \\
\hline Financial & -0.024 & -0.021 & 0.041 & 0.593 & 0.554 \\
\hline $\begin{array}{ll}\text { Literacy } & -> \\
\text { Performance } & \end{array}$ & & & & & \\
\hline $\begin{array}{l}\text { Education Level - } \\
>\text { Performance }\end{array}$ & 0.028 & 0.024 & 0.029 & 0.961 & 0.337 \\
\hline $\begin{array}{l}\text { Entrepreneurship } \\
\text { Orientation -> }\end{array}$ & 0.081 & 0.087 & 0.046 & 1.735 & 0.083 \\
\hline $\begin{array}{l}\text { Performance } \\
\text { Independence } \quad-> \\
\text { Performance }\end{array}$ & 0.730 & 0.717 & 0.097 & 7.548 & $0.000 * * *$ \\
\hline $\begin{array}{l}\text { Emotional } \\
\text { Inteligence -> } \\
\text { Performance }\end{array}$ & 1.188 & 1.186 & 0.099 & 11.955 & $0.000 * * *$ \\
\hline $\begin{array}{l}\text { Motivation -> } \\
\text { Performance }\end{array}$ & -0.194 & -0.195 & 0.067 & 2.919 & $0.004 * * *$ \\
\hline $\begin{array}{l}\text { Financial Aspect - } \\
>\text { Performance }\end{array}$ & -0.033 & -0.035 & 0.048 & 0.686 & 0.493 \\
\hline $\begin{array}{l}\text { the ability to } \\
\text { compile financial } \\
\text { reports -> } \\
\text { Performance }\end{array}$ & -0.808 & -0.804 & 0.111 & 7.304 & $0.000 * * *$ \\
\hline $\begin{array}{l}\text { Performance } \quad-> \\
\text { community } \\
\text { Welfare }\end{array}$ & 0.866 & 0.868 & 0.016 & 13.743 & $0.000 * * *$ \\
\hline
\end{tabular}

*** Significant at $1 \%(2.36712)=$ very significant

Based on table 1, the results of testing using the Smart Pls $3^{\text {rd }}$ method in this study it can be concluded as follows:

a. The test results on the parameter coefficient between financial literacy and the performance of MSME women show insignificant value

b. The test results on the parameter coefficient between the level of education and the performance of MSME women show insignificant value

c. The test results on the parameter coefficient between entrepreneurial orientation and the performance of MSME women showed insignificant value

d. The test results on the parameter coefficient between independence and the performance of MSME women showed significant value

e. The test results on the parameter coefficient between emotional intelligence and the performance of MSME women showed significant value

f. The test results on the parameter coefficient between motivation and the performance of MSME women showed insignificant value

g. The test results on the parameter coefficient between the financial aspects and the performance of MSME women show insignificant value

$\mathrm{h}$. The test results on the parameter coefficient between the ability to prepare financial statements and the performance of MSME women show significant value

i. The test results on the parameter coefficient between the performance capabilities of MSME women and community welfare show significant value 


\section{Conclusions}

This study found that independence, emotional intelligence, motivation, and the ability to compile financial reports had a significant effect on the performance of MSME women in the Bambu Kuning Market, while financial literacy, education level, entrepreneurial orientation, and financial aspects did not significantly influence MSME performance. However, in general, the performance of MSME women in the Bambu Kuning Market influenced the welfare of the community. This indicates that the unique abilities of MSME women in the Bambu Kuning Market play a role in improving people's welfare.

\section{Recommendation}

This study uses only eight independent variables, for future research it is recommended to add other variables such as leadership competency, the success of MSME women in conducting business, especially in management involving the chairman to employees, meaning that leadership competencies can influence success in improving MSME women's performance, relationships competence with performance is very closely related to the impact of the relationship between the two namely causal relationships so that further research can contribute to improving the performance of MSME women. This study still has limitations, namely the limited time and number of research samples that have not been as expected, so that further research needs to add the number of samples and time in conducting research.

\section{Acknowledgement}

The authors would like to acknowledge the support of the Directorate of Research and Community Service, Directorate General Strengthening Research and Development Ministries of Research, Technology and Higher Education of The Republic Indonesia for Research Grants.

\section{References}

[1] BI, Bersinergi Mengawal Stabilitas, Mewujudkan Reformasi Struktural. 2015.

[2] J. Abor and P. Quartey, "Issues in SME development in Ghana and South Africa," Int. Res. J. Financ. Econ., vol. 39, no. 39, pp. 218-228, 2010.

[3] Tulus T.H Tambunan, Usaha mikro dan Menegah di Indoensia: Isu-Isu Penting. 2012.

[4] D. Aribawa, "Pengaruh literasi keuangan terhadap kinerja dan keberlangsungan UMKM di Jawa Tengah,” J. Siasat Bisnis, vol. 20, no. 1, pp. 1-13, 2016.

[5] M. Hasibuan, Manajemen Sumber Daya Manusia. 2012.

[6] Sugiono, Metode Penelitian Pendidikan Pendekatan Kuantitatif, Kualitatif, dan R \& D. 2013.

[7] Husein Umar, Metodologi Penelitian Bisnis Aplikasi dan Pemasaran. 2002. 
